\title{
Implementation of Islamic Religious Education in Building Religious Values for Elementary School Students IT Al Istiqomah Puri Kosambi Karawang
}

\author{
Irwanto Firmansyah ${ }^{1}$, Amirudin ${ }^{2}$, Achmad Junaedi Sitika ${ }^{3}$ \\ 1,2,3 Universitas Singaperbangsa, Karawang, Indonesia \\ Email: irwantofirmansyah@gmail.com
}

\begin{abstract}
To form human beings who are religious and have religious values in themselves, directed education is needed. An educational institution should introduce and instill monotheism or faith to students as the initial foundation before students get to know many other disciplines. Therefore, the purpose of this study was to determine the process of implementing Islamic religious education in building religious values for students at SD IT AI Istiqamah Puri Kosambi Karawang. This research is field research using a qualitative descriptive approach. The results of this study indicate that the implementation of Islamic religious education in building religious values in the SD IT Al Istiqamah Puri Kosambi environment is carried out well and effectively by applying it in daily activities such as getting used to saying greetings, shaking hands, polite in speaking, polite in attitude, and mutual respect both with teachers and fellow friends. In addition, intracurricular learning activities are also carried out centered on students and maximized on aspects of conceptual and illustration material and contextual examples.
\end{abstract}

Keywords: Education, Islamic Religion, Religious Values.

\section{A. INTRODUCTION}

Education is a series of interaction activities between adults and students which are carried out face-to-face or by using the media to provide assistance to the overall development of students (Amirudin, A. \& Muzaki, 2019b). The quality of education can be achieved if the teaching process is effective, directed and in accordance with the learning objectives (Amirudin, A. \& Muzaki, 2019a). Education is one of the most important parts of human life, so that a person's character is largely determined by the good or bad quality of education obtained (Amirudin, 2018).

Education is a life-saving need. Education is a bridge for improving human resources quality (Oktarina, 2007). Education may be done with a purposeful and planned effort to establish a learning environment and process. Students actively develop their potential to have the power, self-control, personality, intelligence of a noble nature and necessary skills of themselves, community, nation and state. Hitler \& Hendriana, 2017). Children's intelligence is not only measured by IQ, because every child has multiple intelligences, namely intellectual intelligence, emotionalsocial intelligence and spiritual intelligence. In addition, to be a successful person, not only requires high intelligence, but also emotional intelligence which is not only 
oriented to human relationships but also based on human relationships with God. (Budianto et al., 2020)

Article 3 of Law No. 20 of 2003 on the National Education System expressly stipulates that national education serves to enhance the capacities of the dignified country and shape its civilization to educate its life. In this sense, it is the school that supports the achievement of the instructional function most importantly. Schools can build and mold the skills of all pupils. Schools have a moral obligation to make kids clever and positive (Subianto, 2013). Murthy said that skills, creativity, and independence are three very important things that every student must have in order to be able to face the reality of life, be creative in providing solutions to existing problems (Amirudin, I., 2020).

In character education, there are several values, one of which is religious values. From an etymological point of view, value is price, degree. Meanwhile, in terms of terminology, value is an empirical quality that is sometimes difficult or cannot be defined. So values are the basis that can influence humans in choosing and doing everything or actions that will be carried out following their beliefs and beliefs (Octaviani et al., 2019).

Religion is a source of religious values and has a very close relationship to enter into one's soul. In shaping the behavior or behavior of a person who can distinguish and can also determine the good or bad of something, even religious values are used as guidelines (Putra, 2015). Therefore, it can form a human being who has a good personality in behavior (Rifa'I, 2016). Pancasila also contains religious values, which lie in the first principle, which reads "Belief in the One Supreme God." What is embedded in this first precept, namely God Almighty, does not mean the One God, but rather the noble qualities or the beginning of God that absolutely must exist? This is related to the diversity of religions in Indonesia, which makes the Indonesian state itself gives freedom to its people to choose their respective religions according to their beliefs.

Religious values are one of the characteristic values utilized in religious teachings for respectful attitudes and behaviours, accepting of other faiths' worship and living in harmony with followers of other religions (Putry, 2019). Students need to deal with the temporal changes and moral degradation that this religious character is present now. In this situation, pupils should, depending on religious provisions and provisions, be permitted to have and to act with good and bad measures. Three methods of character education may be established to cultivate the religious characters: incorporated into topics, school culture, extracurricular (Ahsanulkhaq, 2019).

Education is one of the influential forums informing religious values (Rafsanjani \& Razak, 2019). Parents have given the trust to educational institutions to nurture and educate their children. Therefore, as an educational institution that has received and is deemed capable of carrying out its obligations as entrusted by parents, the school must be able to create a learning atmosphere or a pleasant learning environment so that it can develop and shape students and the quality of 
education produced, according to social expectations and demands. In other words, when the environment around us has been created well, it will produce good humans too, and vice versa (Wahyuni et al., 2013).

The inculcation of religious character through integration in subjects. In this context, subjects that focus on instilling religious character are the subjects of Islamic Religious Education. However, in every subject, the teacher has the right to insert character education in students (Solihin, 2020). So that all aspects support each other and have the same goal. This is following the Law on the National Education System No. 20 of 2003 Article 13 Point a which states that "every student has the right to receive religious education in accordance with the religion he adheres to and is taught by educators of the same religion".4 Regarding religious education and religious education too. It is stated in the Government Regulation of the Republic of Indonesia No. 55 of 2007 Article 3, namely that every education unit at all lines, levels, and types of education is obliged to provide religious education. The minister of religion carries out the management of religious education.

The hope of learning Islamic religious education is that students can practice or implement it in real life. Therefore, Islamic religious education material is studied, but more than that so that students can form individuals with noble character in social life. However, it is not an easy thing to achieve; apart from the efforts that have been made by educators, of course, support from various parties involved in educational institutions is also very much needed (Muslikhin, 2019).

Based on the background above, the researcher will dig deeper into the formation of religious values in these educational institutions, which are implemented in daily attitudes and behavior in the school environment and Islamic religious education. Therefore, researchers are interested in researching the title Implementation of Islamic Religious Education in Building Religious Values for students at SD IT Al Istiqamah Puri Kosambi Karawang.

\section{B. METHOD}

The type of research that the author uses is descriptive qualitative research. According to Moleong, qualitative research is rooted in a scientific background as a whole, relies on humans as research tools, utilizes qualitative methods of inductive analysis, directs research targets to find theories that are more concerned with process than results, selects a set of criteria to write data validity, the research design is temporary. The research results are agreed upon by the research subjects (Moloeng, 2007). Qualitative research methods are, according to Sugiyono (2005), procedures used to investigate the conditions of natural things (Natural Setting). Researchers are an important tool.

This research was conducted in one of the formal educational institutions, namely SD IT Al Istiqamah Puri Kosambi Karawang, located at Jl. Melati 1 Blok Ak No.26, Duren, Kec. Klari, Karawang Regency, West Java. This study aims to understand the Implementation of Islamic Religious Education in Building Students' Religious Values. 


\section{RESULT AND DISCUSSION}

Religion, according to Islam, is carrying out everything that has been ordered and taught in Islamic Law, both from behavior, speech, and attitude. And it is solely done to worship Allah SWT. The order requires every Muslim to always embrace Islam in any place and any circumstances without exception. The implementation of religious values carried out by Islamic religious education teachers at SD IT Al Istiqamah Puri Kosambi Karawang, namely by providing direction and advice to students by teaching them always to speak politely, behave well, provide good examples so that participants Students can imitate it in various ways, such as respecting others, both with older people and with younger people.

The formulation of the vision and mission of SD IT Al Istiqamah Puri Kosambi Karawang has firmly made Islamic values the basis for realizing a leading school in achievement and care for the environment. Therefore, the cultivation of religious character is a priority and several other cultural values and characters. An interesting statement made by the Head of SD IT Al Istiqamah Puri Kosambi Karawang that SD IT Al Istiqamah Puri Kosambi Karawang is a laboratory of life in the religious field. This means that all activities carried out while at school and in the school environment are always based on religious values. For school activities to be based on the foundation of religious values, the Principal said an internalization program for Islamic values was carried out through a series of routine activities carried out in the classroom and the school environment.

The habituation of routine activities and the example displayed by teachers, principals, and the academic community is one way of instilling character in students when they are at school. Students at elementary school age are in the imitation stage. So that the example shown is an effective and efficient step for teaching the character of students. Setiawan (2017) suggests that human learning is not shaped by its consequences but is learned more efficiently from a model (imitation). This imitation goes through four stages: attention, recall, reproduction, and motivation. Students will pay attention to the teacher's example when praying dhuha, reading the Koran, and behaving based on morality, by practicing it and reproducing it. This imitation strategy follows the statement put forward by Hendayani (2019) that internal factors that influence students' character are customs or habits (habits).

For religious values to last long, there must be a process of civilizing religious values. To form a religious culture can be done by educational practitioners, including through 1. Giving examples (Exemplary) 2 and getting used to good things 3 and enforcing discipline, 4 and providing motivation and encouragement, 5 and giving gifts, especially psychological, 6 and punishing in the context of discipline 7. Creating a religious atmosphere that affects children's growth.

Efforts made by the school, especially those carried out by Islamic religious education teachers at SD IT Al Istiqamah Puri Kosambi Karawang in maintaining this religious culture, namely applying it in the form of daily activities in the form of habits that must be carried out by students such as: getting used to the greeting 
culture and accompanied by shaking hands to teachers and friends when they meet, give infaq every Friday, cultivate the habit of reading the Qur'an one hour before the start of learning, getting used to praying dhuha in the congregation, getting used to dhuhur prayers in congregation, then following studies or lectures carried out every Saturday after the dhuhr prayer, as well as habits that are carried out regularly every year, namely holding a prayer together at the time of the national exam,

Then discipline for all school residents was applied at SD IT Al Istiqamah Puri Kosambi Karawang, starting from the neatness of dress, school attributes used, punctuality, and sanctions given to all school residents when violating school regulations at SD IT Al Istiqamah Puri Kosambi Karawang. The role of the school itself is as an educational institution that helps the family environment. And to achieve this goal, all school members, be they principals, educators, and even employees, must work together and make every effort to create a religious, conducive, harmonious school environment and be role models for students.

Implementing religious values at SD IT Al Istiqamah Puri Kosambi Karawang gets full support from various parties because it has become a shared commitment and responsibility. Therefore, school residents (principals, school committees, teachers, students, and staff) try to work together as much as possible to jointly build religious values in the IT Al Istiqamah Elementary School Puri Kosambi Karawang school environment. This can be seen when studies or lectures conducted as resource persons or speakers are charged by Islamic religious education teachers and other teachers in turn. Then the priests for the dhuha prayer and the midday prayer were also performed alternately by all-male teachers at SD IT Al Istiqamah Puri Kosambi Karawang. Likewise, the development of religious-related talents is not only fostered by Islamic religious education teachers. The collaboration is carried out to produce students attached to religious understanding and make graduates who have superior and better spiritual qualities.

These habits that have been implemented in schools are a program that is expected that later students will have the provisions as a basis for moving to the next level by having a sufficient understanding of religion and also having good behavior which can live properly and practice their religion properly and correctly following with the right rules and also according to ethics so that students become human beings with morals.

Habituation that is carried out continuously is expected to have awareness, concern, and are accustomed to applying good things in everyday life. Thus, the daily behavior of students cannot be separated from religious values. The declaration follows Bahri's (2015) opinion, which may be characterized as a compilation of positive traits which form a daily practice. This everyday conduct might be an understanding of the job, duty and task of the mandate and responsibility.

The character values instilled in SD IT Al Istiqamah Puri Kosambi Karawang are discipline, honesty, responsibility, sincerity, tolerance, mutual respect, and care 
for the environment. These character values are instilled through the integration of subjects, school culture, and extracurricular activities.

All teachers at SD IT Al Istiqamah Puri Kosambi Karawang are considered religious teachers. Thus, all teachers must be able to integrate religious values in every subject they teach. The inculcation of religious values at SD IT Al Istiqamah Puri Kosambi Karawang is a task/responsibility for one particular subject and other subjects. Thus, during the learning process, the teacher inserts Islamic values according to their creativity.

Character education planning is carried out when preparing the lesson plan preparation of learning plans in the form of syllabus and lesson plans. Based on the search for documents in each lesson plan contained the values of character education. Regarding the character planting material that the teacher will deliver, it has been neatly and arranged in the RPP (learning implementation plan). So that during the teaching and learning process, it will be easier for the teacher to convey material in which there is character.

School culture is the whole psychological practice of pupils who are engrossed in the school environment, social, emotional, and intellectual. The Strategy for Character Education can be carried out via the modification of school cultures and habitualities through extracurricular self-development, following the Masters Design for Character Education created by the Ministry of Education (2010). The Ministry of National Education proposes four things in the development of the school culture that is being carried out about self-improvement: (1) regular activity; (2) spontaneity; (3) exemplary, and (4) conditioning. SD IT Al Istiqamah Puri Kosambi Karawang is lead by the Ministry of National Education to build a religious-based school culture. Schools are utilized as laboratories for faith; by habitation and example, all school components reinforce religious ideals.

Extracurricular activities are activities that are devoted to honing the talents possessed by students. In this way, the cultivation of religious values through extracurricular activities at SD IT Al Istiqamah Puri Kosambi Karawang is mainly carried out in reading and writing Al-Quran, MTQ (Musabaqah Tilawatil Quran). Other extracurricular development is also inseparable from religious values. Factors that hinder the cultivation of religious values in SD IT Al Istiqamah Puri Kosambi Karawang include internal factors of students, infrastructure factors, and community factors. In general, efforts to instill religious character values in SD IT Al Istiqamah Puri Kosambi Karawang are the efforts of educational institutions to strengthen the prophetic spirit of students. So that graduates from SD IT Al Istiqamah Puri Kosambi Karawang are intelligent and intellectually skilled and have good character (akhlakul karimah) as exemplified by Rasulullah SAW.

\section{CONCLUSION}

Implementing Islamic religious education in building religious values in SD IT Al Istiqamah Puri Kosambi is carried out well and effectively by implementing it in daily activities such as getting used to saying greetings, shaking hands, and being 
polite speaking, polite in attitude, and mutual respect both with teachers. As well as fellow friends. Extracurricular learning is also carried out with student-centered and maximized aspects of conceptual and illustration material and contextual examples. Then the practice is carried out by assessing attitudes and controlling the development of attitudes and religious practices. Conditioning schools created in such a way is done with the hope of making students who believe, obey Allah SWT, have good morals, and have a good social spirit.

\section{REFERENCES}

1. Ahsanulkhaq, M. (2019). Membentuk Karakter Religius Peserta Didik Melalui Metode Pembiasaan. Jurnal Prakarsa Paedagogia, 2(1).

2. Amirudin, A., \& Muzaki, I. (2019a). Rendering Learning Approach with Islamic Religious Education Subjects and Students Accounting XI Relationship with Management and Business. https://doi.org/10.4108/eai.17-10-2019.2289728

3. Amirudin, A., \& Muzaki, I. A. (2019b). Life Skill Education and It'S Implementation in Study Programs Islamic Religious Education. Jurnal Tarbiyah, 26(2), 278-293. https://doi.org/10.30829/tar.v26i2.485

4. Amirudin, I. (2020). Analysis of Policy Development Models for Strengthening Character Education Based on Islamic Education Values in the First Middle Education Unit in Karawang District. Multicultural Education, 6(5), 15-9. https://doi.org/10.5281/zenodo.4393076

5. Amirudin. (2018). Pendidikan Seksual pada Anak dalam Hukum Islam. Jurnal Pendidikan Magister Pascasarjana PAI, 1(1), 14-25.

6. Bahri, S. (2015). Implementasi Pendidikan Karakter Dalam Mengatasi Krisis Moral Di Sekolah. Ta'allum: Jurnal Pendidikan Islam, 3(1), 57-76.

7. Budianto, A., Amirudin, \& Muzaki, I. A. (2020). Peranan Pendidikan Agama Islam dalam Mengembangkan Kecerdasan Spiritual, Emosional, Sosial dan Intelektual Siswa di Sekolah Menengah Pertama (Penelitian di Kelas VIII SMP Islam Telukjambe). Jurnal Wahana Karya Ilmiah, 4(1), 487-497

8. Hendayani, M. (2019). Problematika Pengembangan Karakter Peserta Didik di Era 4.0. Jurnal Penelitian Pendidikan Islam,[SL], 7(2), 183-198.

9. Hendriana, E. C., \& Jacobus, A. (2017). Implementasi pendidikan karakter di sekolah melalui keteladanan dan pembiasaan. JPDI (Jurnal Pendidikan Dasar Indonesia), 1(2), 25-29.

10. Law No. 20 of 2003 concerning the National Education System.

11. Moloeng, L. J. (2007). Metodologi Penelitian Kualitatif Edisi Revisi. Bandung: Remaja Rosdakarya.

12. Muslikhin, M. (2019). Nilai-Nilai Pendidikan Karakter Dalam Pembelajaran Pendidikan Agama Islam. Al-Bahtsu: Jurnal Penelitian Pendidikan Islam, 4(1).

13. Octaviani, A. A., Furaidah, F., \& Untari, S. (2019). Penguatan Pendidikan Karakter Nilai Religius Dalam Program Kegiatan Budaya Sekolah. Jurnal Pendidikan: Teori, Penelitian, dan Pengembangan, 4(11), 1549-1556. 
14. Oktarina, N. (2007). Peranan Pendidikan Global dalam Meningkatkan Kualitas Sumber Daya Manusia. Dinamika Pendidikan Unnes, 2(3), 61996.

15. Putra, K. S. (2015). Implmentasi Pendidikan Agama Islam Melalui Budaya Religius (Religious Culture) di Sekolah. Jurnal Kependidikan, 3(2), 14-32.

16. Putry, R. (2019). Nilai Pendidikan Karakter Anak di Sekolah Perspektif Kemendiknas. Gender Equality: International Journal of Child and Gender Studies, 4(1), 39-54.

17. Rafsanjani, T. A., \& Razaq, M. A. (2019). Internalisasi Nilai-Nilai Keislaman Terhadap Perkembangan Anak di Sekolah Dasar Muhammadiyah Kriyan Jepara. Profetika: Jurnal Studi Islam, 16-29.

18. Rifa'i, M. K. (2016). Internalisasi Nilai-Nilai Religius Berbasis Multikultural Dalam Membentuk Insan Kamil. Jurnal Pendidikan Agama Islam, 4(1).

19. Setiawan, M. A. (2017). Belajar dan Pembelajaran. Uwais Inspirasi Indonesia.

20. Solihin, S. (2020). Peran Guru Pendidikan Agama Islam (PAI) dalam Membina Pendidikan Karakter Peserta Didik. Tafhim Al-'Ilmi, 12(1), 95-111.

21. Subianto, J. (2013). Peran Keluarga, Sekolah, dan Masyarakat Dalam Pembentukan Karakter Berkualitas. Edukasia: Jurnal Penelitian Pendidikan Islam, 8(2).

22. Sugiyono, P. (2005). Memahami Penelitian Kualitatif. Bandung: Alfabeta.

23. Wahyuni, A., Tias, A. A. W., \& Sani, B. (2013, November). Peran etnomatematika dalam membangun karakter bangsa. In Makalah Seminar Nasional Matematika dan Pendidikan Matematika, Prosiding, Jurusan Pendidikan Matematika FMIPA UNY, Yogyakarta: UNY (pp. 112-118). 